\title{
Pop-up: Activation of Abandoned Spaces
}

\author{
Pop-up: Aktivace nevyuživaných prostorů
}

Marie Joja, marie.joja@icloud.com

Ústav stavitelství, Fakulta architektury, Vysoké učení technické v Brně

školitel: doc. Ing. Monika Petříčková, Ph.D.

\begin{abstract}
Contemporary generation called "millenials" comes with a new lifestyle. Therefore market needs to adapt to it in order to keep up with current trends. The generation is provided with almost unlimited opportunities for their own realization. They spend most of their lives online, connected to social networks that determine cultural trends. Sharing experiences through blogs and posting photos is a new form of passing on experience. A difference between live experience and the one absorbed through social platforms is blurred. Enthusiasm for traveling and discovering new things does not match long-term planning and prefers short-term and temporary forms of operation. Therefore this lifestyle opens to pop-up trend. Pop-up is not one of new trends. Pop-up benefits from unlimited possibilities of newly arisen cultural scene as well as a number of abandoned and neglected places in the very centres of cities. Pop-up is a general term used with any form of business including gastronomy or cultural event which is strictly short-term. It profits from a moment of surprise, it offers an unexpected and unique experience "now and here". In the US, the pop-up industry has a long tradition and there exist many servers that provide communication between owners of unused spaces and operators of temporary activities and this trend spreads among continents. Pop-ups abroad, a success of individual projects in the Czech Republic, the Czech pop-up cultural scene supported by a platform for communication and solving problems related not only to the legislative process are questions that will be analysed by this article.
\end{abstract}

KEYWORDS: pop-up; temporary; temporary use; abandoned; vacant; activation; millenials; Brno; distillery; mosilana; industra 


\begin{abstract}
ABSTRAKT: Současná generace přináší nový životní styl, jemuž se trh musí přizpůsobit, pokud chce udržet krok s aktuálními trendy. Generace, kterým se otevřely nepřeberné možnosti vlastní realizace, většinu svého života tráví „online“, připojeny na sociálních sítích, které určují kulturní dění. Sdílení zážitků pomocí blogů a fotek je novou formou předávání zkušeností, stírá se rozdíl mezi skutečným prožitkem a tím předaným prostřednictvím sociálních platforem. Entuziasmus pro cestování a objevování nových věcí se neslučuje s dlouhodobým plánováním a preferuje krátkodobé a dočasné formy fungování. Proto životní styl založený na těchto hodnotách poskytuje prostor pro trend označovaný jako pop-up. Pop-up nepatří mezi nové tendence. Úspěch pop-upu je postaven současně na neomezených možnostech tvorby nově vzniklé kulturní scény a množství opuštěných a zanedbaných míst v samotných centrech dění po ekonomické recesi. Pop-up je obecný termín užívaný v souvislosti s jakoukoliv formou obchodu, stravování nebo události, která je striktně krátkodobá, je založen na principu překvapení, nabízí nečekaný a netradiční zážitek „ted’ a tady“. Pop-up průmysl má již dlouholetou tradici v USA, kde existuje množství serverů, které zprostředkovávají komunikaci mezi majiteli nevyužívaných prostorů a provozovateli dočasných aktivit, a tento trend se širrí dále přes hranice kontinentů. Prŕíspěvek se bude zabývat analýzou otázek pop-up v zahraničí, úspěšnost individuálních projektů v České republice, česká pop-up kulturní scéna podpořená platformou pro komunikaci a řešení problémů spojených nejen s legislativním procesem.
\end{abstract}

KLÍČOVÁ SLOVA: pop-up; dočasný; dočasné využití; aktivace; opuštěná místa; zanedbaná místa; millenials; the distillery; mosilana; industra

\title{
I. Společenské pozadí trendu pop-up
}

Odborníci často připisují znovuobjevení trendu pop-up ekonomickému úpadku po roce 2008. Dlouhodobé podnikání bylo vystřídáno alternativou, která nabízela možnost krátkodobého trvání bez nutnosti plánování a otevírala bránu experimentu, nízkonákladovému provozu a kreativnímu vyžití. Proto se trh musel přeorientovat na poptávku současné generace, tzv. millennials, jejichž potřeby převažují. Nabídka přichází s konceptem pop-up. Pop-up staví na momentu překvapení, objevování nového a nevšedního, a tudíž jsou „millennials“první na mušce. Generace, která prahne po nevšedním zážitku, je často považována za nejpodnikavější generaci všech dob. Není divu, že za provozováním těchto krátkodobých počinů stojí právě ona. Nyní, více než kdy dříve, je úrodná půda pro start vlastního podnikání a krátkodobé podnikání nabízí neomezené možnosti realizace. [1] 


\section{i. Opuštěná místa}

Pop-up aktivity řeší problém s nedostatkem vhodných míst pro provoz nového podnikání objevováním a využíváním starých nepoužívaných prostorů. Umistují do nich dočasné funkce, které jsou přizpůsobovány danému místu, ne naopak, jak je běžné u dlouhodobých aktivit, a vdechují místu nový život. V každém městě se po uplynulé finanční krizi objevuje nespočet míst, která leží ladem a chátrají, která leží ladem a chátrají, protože nejsou prostředky na jejich údržbu, natož další provoz. Proto jsou vhodnými kandidáty na umístění pop-up aktivit, které s sebou vzhledem ke své délce trvání nenesou takové nároky. [2]

\section{Generace „millennials"}

\section{i. Definice}

Přízvisko „millennials“ získala generace narozená na přelomu 2. tisíciletí. Výklad obecně popisuje dvě skupiny, které do této definice spadají: generaci Y, kam patří jedinci narozenív letech 1981-1991, a generaci Z, narozenou v letech 1991-2001. Zásadní rozdíl spočívá v dobovém technologickém vývoji. Generace Y vyrostla na osobních počítačích, mobilních telefonech a videohrách, zatímco generaci $\mathrm{Z}$ ovlivnil příchod tabletů a chytrých telefonů a s nimi spojený rozmach aplikací. Společným znakem obou generací je nicméně změna způsobu komunikace, a to v globální míře. [3]

Členové generace „millennials“ tráví většinu času „online“, připojeni k sociálním médiím, jako jsou blogy, Facebook, Twitter a Instagram, průměrně 2 až 3 hodiny denně [4]. Společnostem, které soutěží o zájem této generace,už nestačí vlastnit facebookový či instagramový profil. Potřebují se dostat do popředí zájmu těch, kteří udávají směr této vlny, at už jsou to prominentní bloggeři, či významná kulturní periodika Sdílení momentů každodenního života pomocí webového rozhraní se dostává na úroveň reálného zážitku. [5]

Tato generace dospěla do doby, která jim otevírá téměř neomezené možnosti rozletu. Díky technologickému pokroku své doby dosahují tito jedinci pracovních úspěchů obecně dřive, než bývalo zvykem. Není výjimkou, že rozjíždí podnikání ještě před dosažením dospělosti. Mnoho z nich postavilo své podnikání na internetu a informačních technologiích. [6]

\section{ii. Zaměstnání}

Současná doba přichází s revolucí v organizaci zaměstnání. Ke standardu již patří 
práce z domova („home office“), volná pracovní doba, volné pracovní místo („mobile working“, „teleworking“), pracovní schůzky online („virtual meetings“) a spoustu dalšího. Změnily se nároky na pracovní místo, s ohledem na vykonávanou profesi mohou zaměstnanci díky technologiím vykonávat svoji práci kdekoli a kdykoli. Výzkum společnosti Flexibility ukázal, že většina pracovních míst je vzhledem ke kombinaci různých faktorů, jako je dovolená, nemoc, práce na poloviční úvazek, schůzky mimo kanceláŕ, vzdělávací kurzy apod., využívána pouze 45-50 procent času. [7]

Fenomén „flexible office“vytvořil poptávku po pracovních místech za zdmi kanceláří a domovů. Ve městech vznikají místa pro setkávání a práci, která se přizpůsobují volné pracovní době, a jejich fungování není omezeno osmihodinovou pracovní dobou. Jedná se o kavárny a „business hubs“, které kromě připojení k síti nabízí další přidané hodnoty, at už k jednorázovým, nebo dlouhodobým pronájmům, např́iklad kávu či tisk v ceně. Nemusí se jednat pouze o celoročně fungující provozy - trendem současné doby jsou dočasné, především letní formy. Jedním z př́kladů je „Summer Pop-up Office“ zprovozněný v roce 2016 pod taktovkou studia KOGAA v Brně v areálu bývalého lihovaru (bližší informace o projektu The Distillery v př́ípadových studiích na konci článku). [8]

\section{Poskytovatelské servery ve světě}

Po celém světě vznikají v návaznosti na rozmach pop-up průmyslu různé typy poskytovatelských serverů. Liší se od sebe nabídkou služeb, ale spojuje je motiv mapování opuštěných míst a zprostředkovávání komunikace mezi majiteli těchto prostorů a potenciálními nájemníky. Kromě toho, že plní roli mediátora mezi těmito stranami, jsou často schopny zprostředkovat další záležitosti, tzv. end-to-end service [9], vedoucí od vytvoření konceptu pop-up aktivity až k jeho realizaci v daných pronajímatelných prostorách a následné činnosti spojené se samotným provozem. Mezi servery fungující na popsaném principu kompletního balíčku služeb patří např́iklad Pop Up Republic ve Spojených státech. Tito poskytovatelé jsou prostředníky, kteři proces využívání opuštěných míst zrychlují a pomáhají tím tato místa zachránit před chátráním. Mají také významný společenský prŕnos - obohacují kulturní dění v daném místě a zvyšují povědomí o aktivitách, které by mnohdy samy, bez napojení na fungující sít poskytovatelů a informačních kanálů, jen těžko hledala uplatnění.

\section{Př́ipadové studie z Brna}

\section{i. The Distillery / Social Reactor}

Architektonická kancelář KOGAA během hledání prostorů pro své studio narazila na objekty starého lihovaru v těsném sousedství městského centra. Toto místo pra- 
covníky kanceláře natolik oslovilo, že se odhodlaně pustili do procesu komunikace s majitelem a navrhování budoucího funkčního uspořádání. Proces rekonstrukce pojali jako experiment, v následných krocích odkrývají historické vrstvy objektu a snaží se o pochopení jeho funkčního a technologického složení. I přesto, že nejsou odborníky, usilují o citlivé očištění konstrukcí při zachování autentického charakteru industriální architektury a za použití citlivých zásahů nutných pro současný fungující provoz. [10]

Objekty nesoucí pracovní název The Distillery na svém počátku fungovaly jako soukromý veřejný prostor ve dvoře komplexu, tzv. POPS - privately owned public space, dále jako prostor pro kanceláře a jako multifunkční prostor, tzv. DepoSite. Tyto prostory jsou $\mathrm{k}$ dispozici k pronájmu na výstavy, workshopy, prezentace produktů, trhy, soukromé večírky, projekce a další události. V letních měsících minulého roku sloužily prostory DepoSite jako summer pop-up office“, v červnu letošního roku se se dočasně na dobu letních prázdnin přesunul provoz kina Art, ve kterém probíhá plánovaná rekonstrukce. Rekonstrukce celého komplexu The Distillery stále probíhá a veřejnosti se $\mathrm{k}$ nahlédnutí nepřetržitě otevírají další prostory, ve kterých postupně vznikají bar, posilovna a další navazující funkce. [11]

\section{ii. Industra}

Areál bývalých brněnských mrazíren byl zprovozněn pod názvem Nezávislý neziskový kreativní klub, který poskytuje svým uživatelům prostor pro představení jejich projektů. V současné době zde návštěvník nalezne širokou nabídku činností. K výstavním prostorům náleží pronajímatelné ateliéry pro umělce, především čerstvé absolventy škol, kterým je nabízena možnost prezentace nejen formou výstav, ale také workshopů a sdílených platforem. Sekce s laboratořemi usiluje o vytvoření prostředí pro inovace a start-upy a zvyšování povědomí veřejnosti o technologickém pokroku. Došlo zde k vytvoření výrobního prostoru a prototypové laboratoře, které byly jako jedny z prvních otevřeny pro odborníky i laickou veřejnost na jižní Moravě. Industra Lab se tak stala fungující základnou pro spolupráci kreativních a technologických oborů. Industra Coffee je již zaběhlou brněnskou kavárenskou značkou, která se zapojuje dodění po celém Brně. $\mathrm{V}$ neposlední řadě Industra Stage patří k jedinečným počinům provozování divadelních činností v industriálních prostorách mimo klasické jevištní provozy. [12]

\section{Závěr / Mediátor}

Současná situace českého prostředí je charakterizována absencí funkční platformy pro poskytovatele, která by stanovila proces legálního povolování dočasné činnosti. Pop-up podniky běží jako jednotlivé experimenty bez jakéhokoli sjednocujícího 
obecného schématu Řada nadějných konceptů dočasného charakteru je tak odsouzena k zániku právě díky byrokratickému systému. Systematický př́istup k dočasné aktivaci volných míst by přinesl výhody všem zúčastněným stranám, nejen vlastníkům nebo nájemcům. Existuje velká poptávka po instituci, která by mohla shromáždit veškerá potřebná data a zpř́istupnit proces spouštění pop-up podnikání. Proces by nejen byl rychlejší, ale také by zabránil zničení mnoha cenných prostor ve městech. Na celém světě lze nalézt mnoho těchto serverů, a to vše na základě přenosu informací od vlastníků ke koncovým uživatelům. Fungují jako zprostředkovatelé, kteří urychlují celý proces aktivace opuštěných městských míst a pomáhají je zachránit před konečným rozpadem. Současně tyto služby přinášejí významné sociální výhod - obohacují kulturní život na daném místě a zvyšují povědomí o činnostech, které je bez pomoci fungující sítě poskytovatelů a informačních kanálů často těžko najít.

\section{Prameny}

[1] Information on http://www.cnbc.com/2015/08/21/f-the-pop-up-business.html

[2] P. Bishop, L. Wiliams, The temporary city, Taylor \& Francis Ltd., Abingdon, 2012, pp. 24-26

[3] Information on http://www.urbandictionary.com/define.php?term=Millennial

[4] Information on http://www.cnbc.com/2015/08/20/millennials-a-generation-to-make-or-break-retailers.html

[5] Information on https://www.inc.com/business-insider/how-twenty-somethings-should-spend-their-free-time.html

[6] Information on https://www.forbes.com/billionaires/list/\#version:static_tab:youngest

[7] P. Bishop, L. Wiliams, The temporary city, Taylor \& Francis Ltd., Abingdon, 2012, pp. 26-28.

[8] P. Bishop, L. Wiliams, The temporary city, Taylor \& Francis Ltd., Abingdon, 2012, pp. 26-28.

[9] Information on https://popuprepublic.com/

[10] V. Ruppert, Radio interview with Tomáš Kozelský and Viktor Odstrčilík, (2017). Information on: http://www.rozhlas.cz/radiowave/modeschau/_zprava/1730131

[11] Information on http://takatukaphoto.com/filter/others/Distillery-Social-Reactor

[12] Information on http://www.gotobrno.cz/industra 


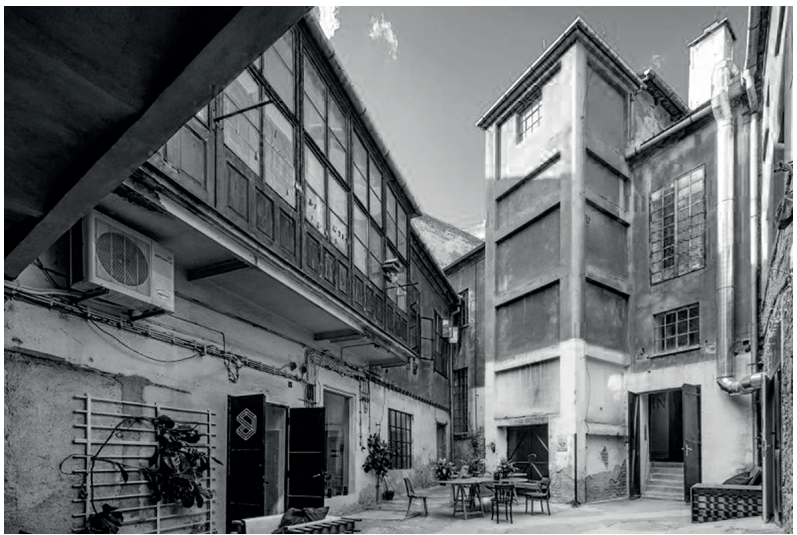

Obr. 1. Nádvoří objektů The Distillery (Zdroj: www.ticbrno.cz)

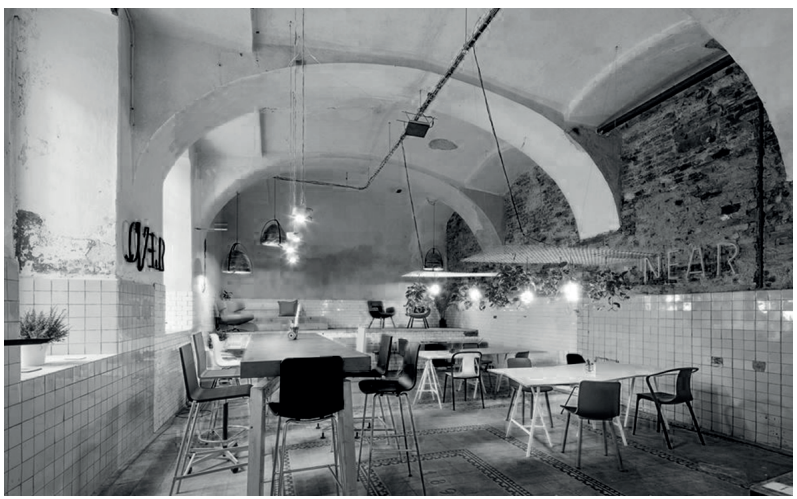

Obr. 2. Multifunkční prostor (Zdroj: www.lukaspelech.com)

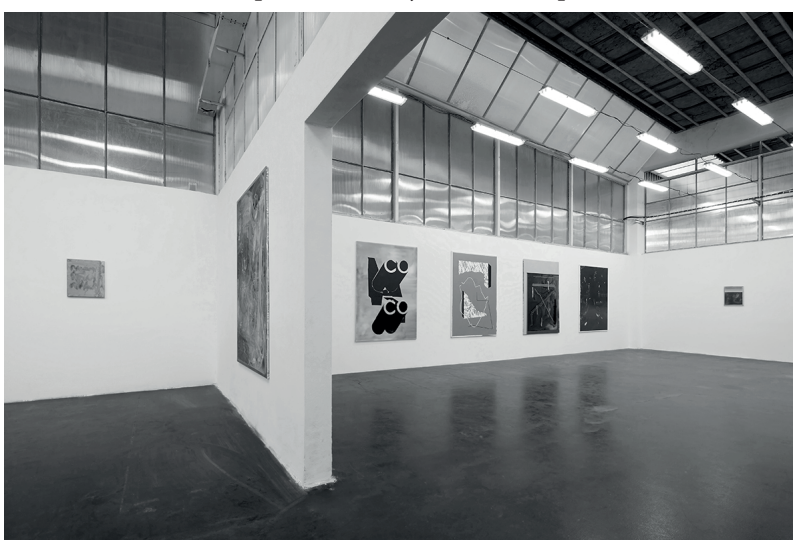

Obr. 3. Industra Art (Zdroj: industra.space) 